\title{
Genetic structure and Genetic Diversity of SWIETENIA MACROPHYLLA IN AREAS SUBJECTED TO SELECTIVE LOGGING in Quintana RoO, Mexico
}

\author{
Raúl Ernesto Alcalá ${ }^{1,3}$, Silvia De la Cruz and Gabriel Gutiérrez-Granados ${ }^{2}$ \\ 'Departamento de Ecología Evolutiva. Centro de Investigación en Biodiversidad y Conservación, \\ Universidad Autónoma del Estado de Morelos. Cuernavaca, Morelos, México. \\ ${ }^{2}$ Laboratorio de Sistemas de Información Geográfica, Instituto de Biología, \\ Universidad Nacional Autónoma de México, México D. F., México. \\ ${ }^{3}$ Corresponding author: raul.alcala@uaem.mx
}

\begin{abstract}
The hypothesis that selective logging has a negative effect by altering the genetic parameters of tropical tree species was evaluated. The genetic diversity and genetic structure between adult trees $(N=47)$ and saplings $(N=50)$ of Swietenia macrophylla were contrasted within an area subjected to selective logging in the Mayan zone. Although differences in the number of alleles and in their frequencies were detected between both groups, the observed and expected heterozygosity and the coefficient of fixation were statistically similar. Evidence of higher genetic structure in the group of saplings was revealed by both, the autocorrelation and the factor correspondence analyses. The genetic differences observed in this study are compatible with those expected under scenarios of disruption in the local pattern of gene flow produced by selective logging. The implication of these results on the conservation genetics of Swietenia macrophylla in the Mayan zone is discussed.
\end{abstract}

Keywords: autocorrelation analysis, big-leaf mahogany, conservation genetics, Moran's index, tropical timber species.

Resumen: Se evaluó la hipótesis de que la tala selectiva genera un efecto negativo alterando los parámetros genéticos de las especies de árboles tropicales. Se contrastó la diversidad genética y la estructura genética entre árboles adultos $(N=47)$ e individuos juveniles $(N=50)$ de Swietenia macrophylla en una zona sujeta a la tala selectiva en la zona maya. Aunque se detectaron diferencias entre ambos grupos de árboles en el número de alelos y en sus frecuencias, la heterocigosis observada y la esperada, y el coeficiente de fijación fueron estadísticamente similares. Análisis de autocorrelación espacial y factorial de correspondencias mostraron una mayor estructura genética en el grupo de individuos juveniles. Las diferencias genéticas observadas en este estudio son compatibles con las esperadas bajo escenarios de perturbación en el patrón local del flujo de genes producto de la tala selectiva. Se discute la implicación de estos resultados en la conservación genética de Swietenia macrophylla en la zona maya.

Palabras clave: análisis de autocorrelación espacial, caoba de hoja grande, conservación genética, especies tropicales maderables, índice de Morán.

B iodiversity is currently threatened, directly or indirectly by human activities in almost all terrestrial habitats. Due to this, in conservation biology it is important to understand how species respond to anthropic disturbances (Sih et al., 2000; Cushman, 2006). This challenge is particularly relevant for tropical forests because these biomes sustain both, high species richness and a high level of human-induced disturbance (Lowe et al., 2005; Wright and Muller-Landau, 2006). Tropical trees are expected to be particularly susceptible to changes in habitat characteristics because of their

low population density (ca. one reproductive tree $\times$ ha $^{-1}$ ), self-incompatibility systems and their frequent dependence on animals for pollination (Cunningham, 2000; Lowe et al., 2005; Dick et al., 2008).

The selective logging of target trees with the best characteristics is the commonest strategy in most tropical forests subjected to legal harvesting (Jennings et al., 2001; Sist et al., 2003; Asner et al., 2005; Biscaia-de Lacerda et al., 2008). Selective logging is conceived as a sustainable strategy of forest management due to its intensity is based 
on growth rates (Snook, 2003; Shono and Snook, 2006). However, it has been proposed that selective logging could impact directly on the local pattern of gene makeup as it tends to reduce population size and/or population density and because it increases the distance between reproductive individuals (Sebbenn et al., 2008). Therefore, the extraction of reproductive trees subsequently reduces outcrossing rates (Murawski et al., 1994; Lee, 2000; Obayashi et al., 2002), increases inbreeding (André et al., 2008) as well as the extent of genetic differentiation (Degen et al., 2006; Cloutier et al., 2007; Biscaia-de Lacerda et al., 2008; Sebben et al., 2008; Silva et al., 2008).

Swietenia macrophylla King in Hook is undoubtedly the most important timber species in Neotropics. It has being traded along its entire geographic distribution, which ranges from the Amazon Basin to South Mexico (Snook, 1998). In Mexico, S. macrophylla has been logged since the late $19^{\text {th }}$ century. With the implementation of federal regulations (Plan Piloto Forestal) by the 1980s the harvesting plans performed in the so-called Mayan zone (central part of Quintana Roo), included initial inventories and the determination of growth rates. Currently, the management plan is based on polycyclic harvesting with 25 -y cutting cycles and a minimum cutting diameter of $55 \mathrm{~cm}$ (Bray et al., 2003).

An important consequence of the extraction of largest individuals for timber is that regeneration relies on smallsize remnant trees (Gutiérrez-Granados and Dirzo, 2009). As a result, natural regeneration could be limited by a low fruit production, restricted seed shadow, increased seed predation, and a high rate of herbivory in young ontogenetic stages (Snook et al., 2005; Cámara-Cabrales and Kelty, 2009; Gutiérrez-Granados et al., 2011). However, studies addressing the effects of selective logging on genetic parameters are currently absent for Mexican populations of $S$. macrophylla. If selective logging is exerting some effect on population dynamics, we expect to find genetic differences between the group of adult trees and that derived by the natural regeneration. In particular, it is predicted a higher spatial genetic structure (i.e., higher genetic relatedness at short distances) and lower genetic diversity in saplings rather than in adult trees.

\section{Materials and methods}

Study site. Fieldwork was carried out in the ejido (communal owned lands) named Señor X-Maben, that is located in the municipality of Felipe Carrillo Puerto $\left(19^{\circ} 00^{\prime}-20^{\circ} 00^{\prime}\right.$ $\mathrm{N}$ and $88^{\circ} 00^{\prime}-88^{\circ} 20^{\prime} \mathrm{W}$; Figure 1). The predominant vegetation is tropical moist forest (sensu Holdridge, 1967), with intermingled patches of savanna and flooded forest (Gutiérrez, 2010). Tree species as Brosimum alicastrum Sw., Bursera simaruba (L.) Sarg., Cedrela odorata L., Caesalpinia mollis (Kunth) Spreng., Coccoloba spicata Lundell, Cordia dodecandra DC., Lysiloma bahamense Benth., Manilkara

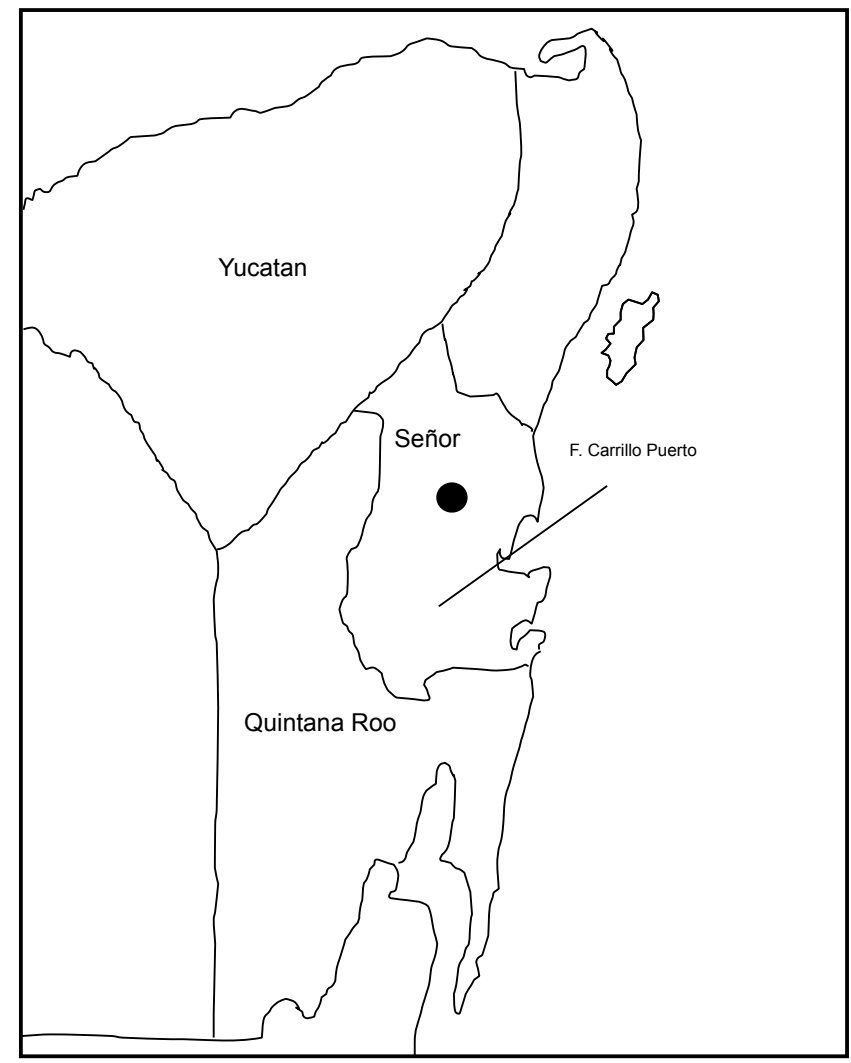

Figure 1. Location of the study site (Señor) within the municipality of Felipe Carrillo Puerto in Central Quintana Roo, Mexico.

zapota (L.) Royen, Metopium brownei Urb., Piscidia communis Harms, Platymiscium yucatanum Standl. and Pouteria reticulata (Engl.) Eyma are also present in the zone (Rebollar-Domínguez et al., 2002; Vester and Navarro-Martínez, 2005).

Sampling design. Some studies sampling only adult trees have shown an apparent absence of negative effects of selective logging, forest fragmentation or deforestation on genetic parameters. This result has been explained by considering these anthropic disturbances as relatively recent processes with regard to the long-life span of adult trees (White et al., 1999; Collevatti et al., 2001; Lowe et al., 2005). Therefore, a more informative approach has been derived from the genetic comparison between adults and their regeneration, assuming that the disruption of processes affecting gene flow between adult trees (i.e., pollination) should produce measurable effects on progeny.

Genetic analyses were performed on 47 adult trees and 50 saplings of Swietenia macrophylla located within a 600ha forest surface subjected to a first cutting cycle in 1998. Originally 160 individuals were mapped in the area; however, individuals separated from each other by at least $100 \mathrm{~m}$ were selected in order to avoid the probability of sampling within genetic families (Gillies et al., 1999; Navarro et al., 2010). 
Diameter at breast height (DBH $1.30 \mathrm{~m}$ ) of adult trees ranged from 35 to $45 \mathrm{~cm}$, whereas height of saplings was $<50 \mathrm{~cm}$. For adult trees, a slingshot was used to obtain leaves from the upper part of the crown, whereas a telescopic pruner was used to sample at lower height. Only the leaves free of apparent damage by pathogens and insects were selected. The sampled tissue per plant was kept in previously marked sealed plastic bags containing blue indicator silica gel to stabilize DNA through a rapid desiccation of plant material.

DNA-procedures. Isolation of DNA was performed through a standard Cetyl Trimethyl Ammonium Bromide (CTAB)based procedure (Doyle and Doyle, 1987). Quality of samples was improved by applying GENECLEAN ${ }^{\circledR}$. A set of primers Sm01, Sm31, Sm47 and Sm51 were used from those developed for Swietenia macrophylla (Lemes et al., 2002). The final reaction consisted of $15 \mu \mathrm{l}$ total volume containing $1 \times$ PCR buffer, $1 \mathrm{mM} \mathrm{MgCl}, 0.2 \mathrm{mM}$ dNTP's, 1 $\mu \mathrm{L}$ Taq DNA polymerase (Vivantis Technologies, Selangor, Malaysia) and $5 \mathrm{ng}$ of template DNA. Amplification conditions for primer $\mathrm{sm} 47$ were: an initial denaturing step of 95 ${ }^{\circ} \mathrm{C} 1 \mathrm{~min}$ followed by 30 cycles of $95^{\circ} \mathrm{C} 1 \mathrm{~min}, 56{ }^{\circ} \mathrm{C} 1 \mathrm{~min}$ and $72{ }^{\circ} \mathrm{C} 1 \mathrm{~min}$, and a final extension step of $72{ }^{\circ} \mathrm{C} 10 \mathrm{~min}$. For the other three primers the conditions were: an initial step of $94{ }^{\circ} \mathrm{C}$ for $3 \mathrm{~min}$ followed by 30 cycles of $1 \mathrm{~min}$ at 94 ${ }^{\circ} \mathrm{C}, 1 \mathrm{~min}$ at $56^{\circ} \mathrm{C}, 4 \mathrm{~min}$ at $72{ }^{\circ} \mathrm{C}$ and an extension step of $72{ }^{\circ} \mathrm{C} 10 \mathrm{~min}$. PCR products were subjected to electrophoresis in $6 \%$ polyacrilamide gel in Tris-Borate Ethylenediaminetetraacetic acid (TBE) buffer. Gels were stained with ethidium bromide and photographed under UV light. Then, the different alleles for each locus were scored according to their molecular mass (White et al., 2002; Céspedes et al., 2003). The allele located closer to anode was arbitrarily identified as "1", and the remaining alleles were identified sequentially (Céspedes et al., 2003).

Statistical analyses. The genetic differences between adults and saplings of Swietenia macrophylla were analyzed with four different approaches, allelic frequencies, heterozygosity-based information, autocorrelation analysis and factor correspondence analysis. For the allelic information, the total number of alleles found in the population, the number of alleles per locus and their respective allelic frequencies were described. In addition, the alleles present in eight frequency classes for adults and saplings were counted. The statistical differences between both groups were tested by a contingency table (Sokal and Rohlf, 1995). Second, the mean values for both the observed heretozygosity $\left(H_{\mathrm{O}}\right)$ and expected heterozygosity $\left(H_{\mathrm{E}}\right)$ were calculated using ARLEQUIN (Excoffier et al., 2005). The coefficient of fixation $\left(F_{\text {IS }}\right)$ that indicates departures of genotypic frequencies from Hardy-Weinberg equilibrium was also estimated. The significance of the coefficients $F_{\text {IS }}$, were tested using a Monte Carlo chain with 1,000 iterations (Excoffier et al., 2005).
Genetic differences between adults and saplings regarding these tree estimates were evaluated performing independent Mann-Whitney tests (Sokal and Rohlf, 1995).

Third, three independent spatial autocorrelation analyses were performed to investigate differences between both groups in the fine-scale genetic structure (Degen et al., 2001). The autocorrelation analysis has been used to identify a series of processes that affect the local pattern of gene flow and that consequently shape the fine-scale genetic structure (Smouse and Peakall, 1999; Degen et al., 2001; Vekemans and Hardy, 2004). The spatial autocorrelation analysis performed on the molecular information evaluates if the pairwise genetic relatedness varies depending on the separation distance of the compared individuals. From this relationship, a spatial random distribution is expected as a null hypothesis. Instead, a higher genetic relatedness at shorter distances is expected under conditions restricting gene movement.

The SGS software utilized in this study to perform the autocorrelation analyses returned correlograms displaying the variation in the magnitude of the Moran's Index (genetic relatedness) obtained for multilocus genotypes according with the separation distance of pairs of individuals. Along the $x$-axis of the correlograms, the variation in the separation distance between compared individuals is displayed in the form of ranges (distance classes; Degen, 2000). A permutation procedure using Monte-Carlo simulations was applied to test for significant deviation from the spatial random distribution. For each one of the spatial distance classes, observed values were compared with the distribution obtained after 1,000 permutations. Then, a $95 \%$ confidence interval for the parameters was obtained. Thus, positive values of Moran's Index located beyond the confidence limit represent statistically significant deviations of the random distribution (positive fine-genetic structure). The consistency of the genetic spatial pattern was evaluated varying the number of distance classes. To do this, three analyses per group were performed using 5, 7, and 15 distance classes. In all cases, at least 30 pairs of data points per distance class were used (Degen, 2000).

Finally, a factorial correspondence analysis was carried out using GENETIX 4.05.2 (Belkhir et al., 1996-2000). With this analysis, the genetic structure was qualitatively examined by comparing the extent of genetic variation displayed for both groups in a multivariate space. A strong overlapping in the distribution pattern between adults and saplings would indicate the absence of genetic differences between them.

\section{Results}

Genetic diversity. The information extracted from the four loci utilized in this study revealed a total of 25 alleles. The genetic polymorphism varied lightly among loci. The lowest 
Table 1. Allelic frequencies for adults and saplings of Swietenia macrophylla per microsatellite locus.

\begin{tabular}{|c|c|c|}
\hline Locus & Adults & Saplings \\
\hline $\mathrm{Sm} 22$ & \multicolumn{2}{|c|}{ Allelic frequencies } \\
\hline 1 & 0.1625 & 0.2708 \\
\hline 2 & 0.2625 & 0.2396 \\
\hline 3 & 0.0500 & 0.1563 \\
\hline 4 & 0.325 & 0.1979 \\
\hline 5 & 0.2000 & 0.1354 \\
\hline \multicolumn{3}{|l|}{$\mathrm{Sm} 31$} \\
\hline 1 & 0.0556 & 0.0301 \\
\hline 2 & 0.0778 & 0.0000 \\
\hline 3 & 0.1889 & 0.0602 \\
\hline 4 & 0.3001 & 0.3711 \\
\hline 5 & 0.2111 & 0.2311 \\
\hline 6 & 0.1666 & 0.3102 \\
\hline \multicolumn{3}{|l|}{ Sm47 } \\
\hline 1 & 0.0465 & 0.0417 \\
\hline 2 & 0.0465 & 0.0418 \\
\hline 3 & 0.1861 & 0.2083 \\
\hline 4 & 0.1863 & 0.1875 \\
\hline 5 & 0.1861 & 0.3229 \\
\hline 6 & 0.2791 & 0.1979 \\
\hline 7 & 0.0698 & 0 \\
\hline \multicolumn{3}{|l|}{ Sm51 } \\
\hline 1 & 0.0349 & 0.0106 \\
\hline 2 & 0.1512 & 0.0957 \\
\hline 3 & 0.0233 & 0.1277 \\
\hline 4 & 0.3023 & 0.2979 \\
\hline 5 & 0.0814 & 0.0319 \\
\hline 6 & 0.2791 & 0.2872 \\
\hline 7 & 0.1279 & 0.1489 \\
\hline
\end{tabular}

number of alleles (5) was observed for locus Sm22, whereas loci Sm51 and Sm 47 revealed the occurrence of seven alleles (Table 1). In the group of adults, 21 alleles showed a frequency equal or higher to 0.05 . In contrast, in the group of saplings seven alleles showed a low frequency $(<0.05)$. In fact, two alleles present in adult trees were absent in that group, whereas all alleles present in saplings were detected in adult trees.

The analysis of the distribution of allelic frequencies showed significant differences between adults and saplings

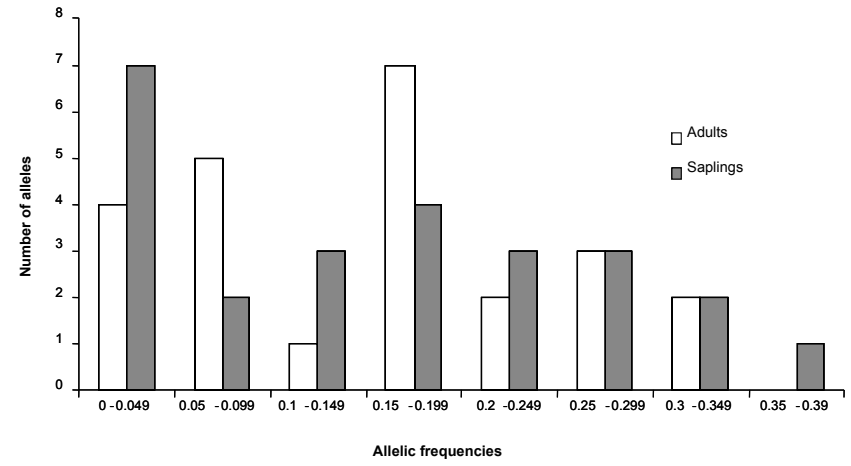

Figure 2. Differences in allelic frequencies between adults and saplings of Swietenia macrophylla.

$\left(\chi^{2}=23.37, \mathrm{df}=7, P=0.0014\right.$, Figure 2). Differences were present in most of the frequency categories, in particular on alleles at frequencies $<0.25$ (Figure 2). With regard the genotypic information, in both groups, the observed heterozygosity $\left(H_{\mathrm{O}}\right)$ was markedly lower than expected heterozygosity $\left(H_{\mathrm{E}}\right)$ for all loci. In consequence, positive values for the coefficient of fixation $\left(F_{\text {IS }}\right)$ were obtained that indicate a statistically significant deficiency of heterozygotes (Table 2). No statistical differences in $H_{\mathrm{O}}, H_{\mathrm{E}}$, and $F_{\text {IS }}$ between adults and saplings were detected by the independent Mann-Whitney tests (Table 2).

Genetic structure. The three autocorrelation analyses performed for both adults and saplings showed consistent results. This means that the relationship between the genetic relatedness of individuals with spatial distance was not affected by the variation in the number of distance classes ( 5 , 7 or 15). No departures from a random pattern were detected in the analysis corresponding to adults. This is because the values for the Moran's Index were constrained within the confidence limits along the variation in the separation distance between compared individuals (Figure 3). In contrast, a statistically significant fine-scale genetic structure was observed for saplings. In this group, positives values of the Moran's Index (ca. 0.05 of magnitude) were situated beyond the confidence limit along the first $1,000 \mathrm{~m}$ of separation distance (Figure 3). This indicates the occurrence of individuals that are more genetically related than the expected by random.

Table 2. Observed heterozygosity $\left(H_{\mathrm{O}}\right)$, expected heterozygosity $\left(H_{\mathrm{E}}\right)$ and coefficient of fixation $\left(F_{\mathrm{IS}}\right)$ for adults and saplings of Swetenia macrophylla.

\begin{tabular}{lcccccc}
\hline & Adults & & & \multicolumn{2}{c}{ Saplings } \\
\hline Locus & $H_{\mathrm{O}}$ & $H_{\mathrm{E}}$ & $F_{\mathrm{IS}}$ & $H_{\mathrm{O}}$ & $H_{\mathrm{E}}$ & $F_{\mathrm{IS}}$ \\
Sm22 & 0.3861 & 0.7923 & 0.5128 & 0.2979 & 0.7884 & 0.6222 \\
Sm31 & 0.5348 & 0.8186 & 0.3446 & 0.5417 & 0.7827 & 0.3079 \\
Sm47 & 0.5777 & 0.7981 & 0.2782 & 0.2801 & 0.7168 & 0.6094 \\
Sm51 & 0.2075 & 0.7661 & 0.5986 & 0.2625 & 0.7956 & 0.6701 \\
Mean & 0.4516 & 0.7938 & 0.4335 & 0.3455 & 0.7709 & 0.5524 \\
\hline
\end{tabular}


A)

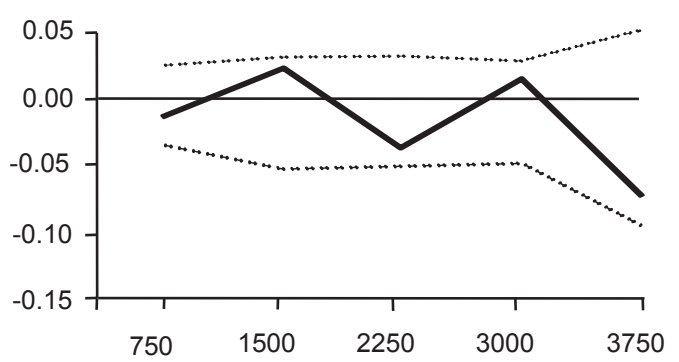

B)

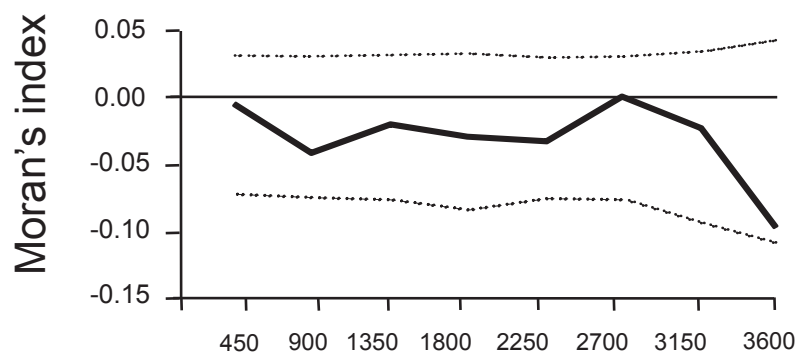

C)

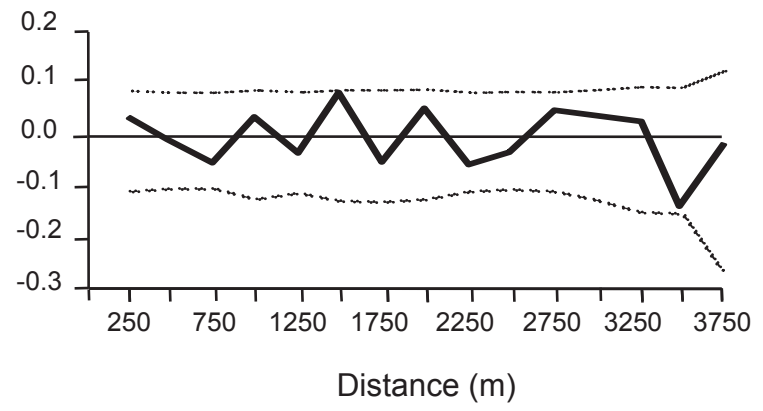

Saplings
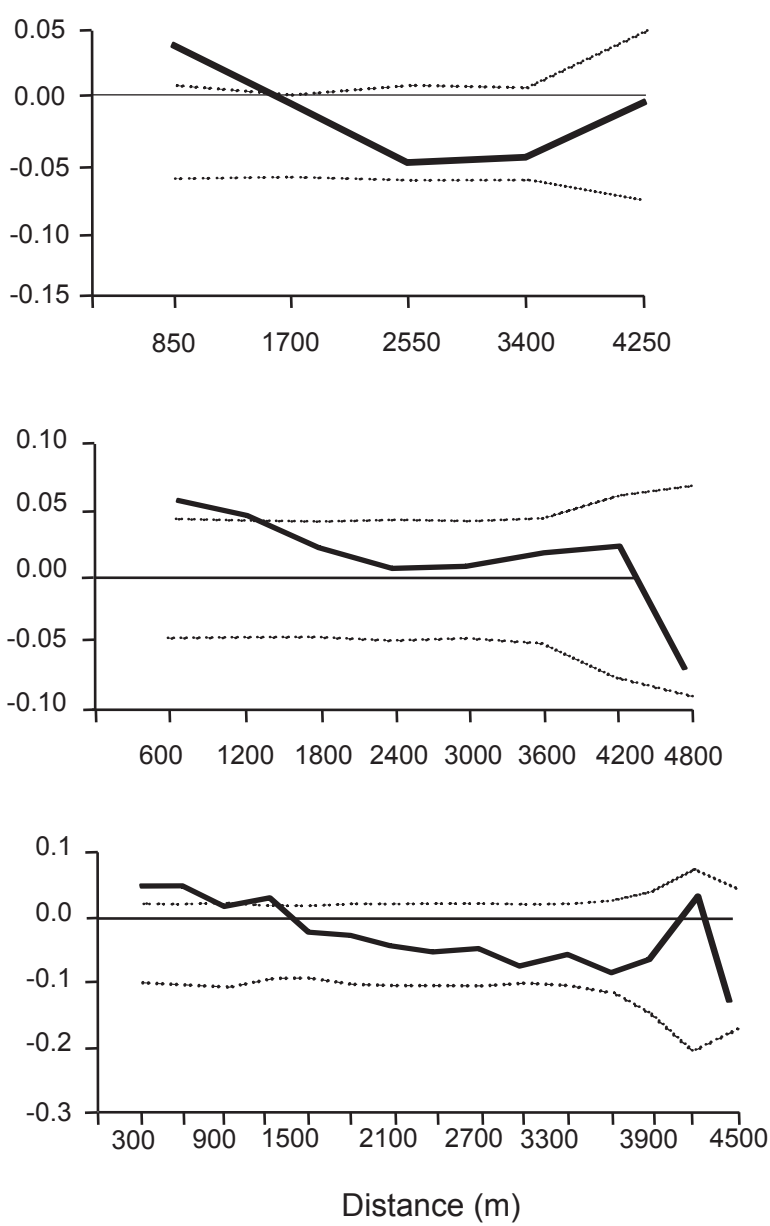

Figure 3. Correlograms for adults (left) and saplings (right) of Swietenia macrophylla showing the relationship of the Moran's Index (D, continuous line $\pm 95 \%$ CI broken lines) with the separation distance between pairs of individuals. Significant values of Moran's Index are those situated beyond the CI.

The information summarized by the first two axes derived from the factorial correspondence analysis explained $37 \%$ of the total variance and showed genetic differences between adults and saplings (Figure 4). In this multivariate space, the scores of saplings along Axis 1were constrained between -0.7 and 0.7 . In contrast, the scores of adult trees ranged between -1 and 1.5 for the same Axis 1 . The coefficients of adults also showed a higher variation on the Axis 2 (Figure 4).

\section{Discussion}

The management implemented in the Mayan zone has received international acknowledgement as a low impact, socially fair and a community-based forestry program (Bray et al., 2003). However, recent ecological evidence obtained for Swietenia macrophylla indicates the existence of negative effects of selective logging on different components related with its natural regeneration. For example, selective logging limits fruit production (Snook et al., 2005), seed dispersal (Cámara-Cabrales and Kelty, 2009) and increase both, the risk of herbivory and seedlings mortality (Gutierrez-Granados et al., 2011). In accordance with our prediction, the genetic differences detected in this study between adults and saplings of $S$. macrophylla are compatible with those expected under conditions of selective logging.

Genetic diversity. Overall, our results were similar to those reported for other Mexican populations of Swietenia macrophylla sampled within the Yucatan peninsula and analyzed with microsatellite loci. For example, Trujillo-Sierra et al. (2013) reported from 21 to 26 alleles per population (29 alleles in total), whereas 25 alleles were reported in this study (in the group of adults for comparison). Mean values of the observed heterozygosity $\left(H_{\mathrm{O}}\right)$ of 0.420 and 0.410 has been reported respectively by Trujillo-Sierra et al. (2013) and by Alcalá et al. (2014), which coincide with our estimate of 0.451 . These two studies also showed a statistically signifi- 


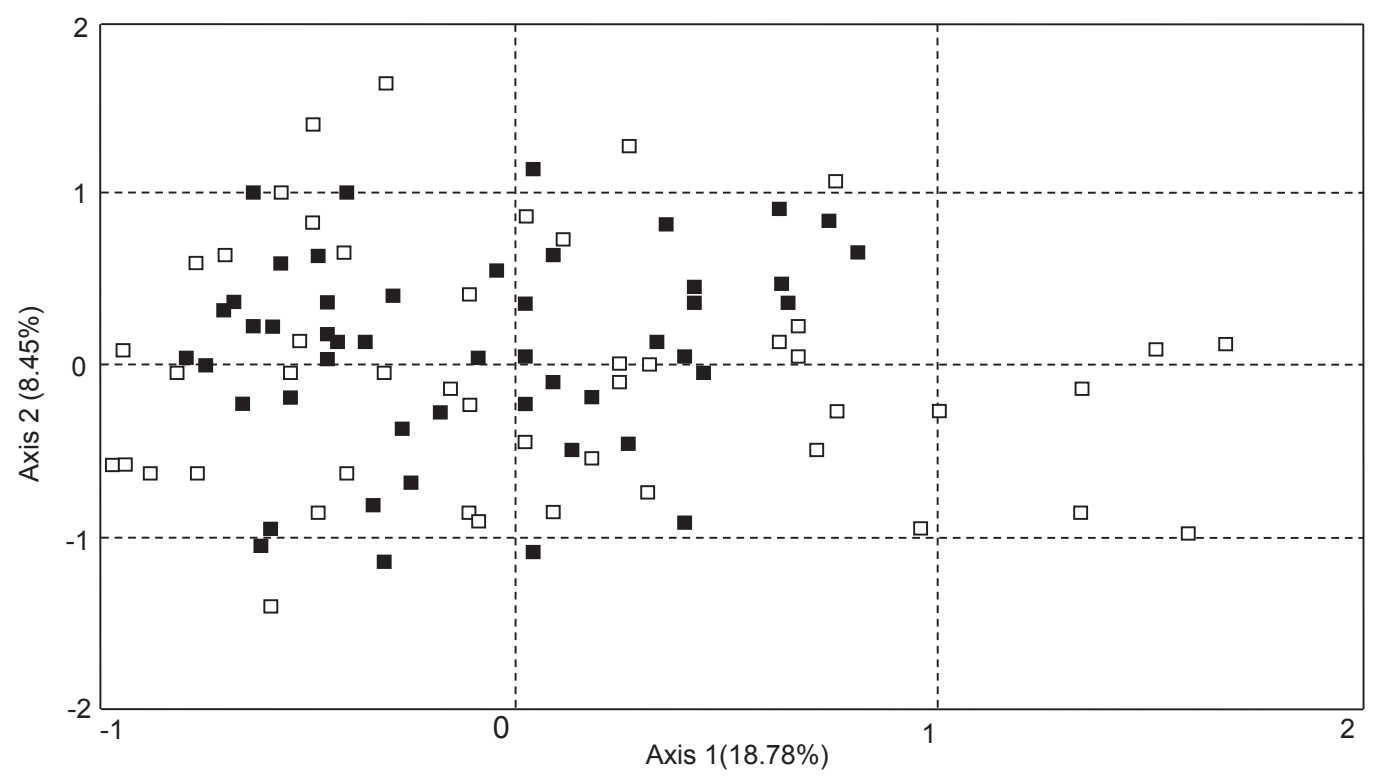

Figure 4. Biplot derived from the factorial correspondence analysis for Swietenia macrophylla (white markers $=$ adults, black markers $=$ saplings).

cant deviation of the genotypic frequencies, revealing a high coefficient of fixation ( 0.309 and 0.449 , respectively). In this study, a mean value for the $F_{\text {IS }}$ was 0.43 . All the results involving allelic and genotypic information indicate that Mexican populations could maintain overall low levels of genetic diversity and high scores for the coefficient of fixation by historic reasons. This is because there is evidence that suggests that northern populations of Swietenia macrophylla maintain lower heterozygosity due to the colonization toward northern latitudes from South America (Lemes et al., 2003, Novick et al., 2003), a pattern that is still observed along the distribution of this species in Mexico (Alcalá et al., 2014).

Statistically significant differences between adults and saplings were detected for the number of alleles present at different frequency categories. In fact, saplings of Swietenia macrophylla showed lower polymorphism, lacking of two alleles that were present in adult trees. These results are similar to the reported for other tree species subjected to selective logging (Rajora et al., 2000; Silva et al., 2008). Interestingly, no statistical differences between adults and saplings of $S$. macrophylla were found for the mean values of $H_{\mathrm{O}}$, $H_{\mathrm{E}}$, and the coefficient of fixation $\left(F_{\mathrm{IS}}\right)$. Although a clear reduction in $H_{\mathrm{O}}$ and a statistically significant increase in the coefficient $F_{\text {IS }}$ have been reported for S. macrophylla as a result of selective logging (André et al., 2008), most studies in other tree species have not reported at a short-term, genetic differences between logged and unlogged populations (Rajora et al., 2000; Cloutier et al., 2007; Sebbenn et al., 2008; Silva et al., 2008), fragmentation and habitat degradation (Lowe et al., 2005), and even at a long-term as revealed by simulation models (Young et al., 1996; Degen et al., 2006; Sebbenn et al., 2008). Therefore, although changes in al- lelic frequencies and loss of rare alleles produced by selective logging have been commonly detected (Rajora et al., 2000, Silva et al., 2008, this study), heterozygosity seems to be highly resilient to the reduction in population size. This is because under neutrality, the theoretically per generation rate of loss of heterozygosity is set at $1 / 2 \mathrm{Ne}$ (Franklin, 1980). At this rate, population reductions should occur at a very high magnitude to produce marked reductions, as the loss of rare alleles (those that are lost first) shows a limited effect on this parameter in the short-term (Hedrick, 2000). However, the absence of differences in heterozygosity between adults and saplings may be explained by the overall low levels of genetic diversity that Mexican populations sustain as a result of the expansion of its geographic range, as explained above (Lemes et al., 2003, Novick et al., 2003; Alcalá et al., 2014).

Genetic structure. The occurrence of a fine-scale genetic structure has been commonly detected in plant populations through the implementation of autocorrelation analysis. In particular, some ecological factors affecting local patterns of gene movement have been advanced to explain the fine-scale genetic structure observed in tropical trees. For example, in adults of Dicorynia guianensis Amshoff the within-population genetic structure resulted from tolerance to selfing, overlapping generations or selection (Latouche-Hallé et al., 2004). In adults of Swietenia macrophylla (Lowe et al., 2003) and Simarouba amara (Hardesty et al., 2005) autocorrelation resulted as a consequence of restricted seed dispersal, whereas in Bagassa guianensis Aubl. the genetic structure was due to biparental inbreeding (Silva et al., 2008).

In this study, no evidence of fine-scale genetic structure in the group of adult trees was found. However a positive genet- 
ic structure was found in the group of saplings. The genetic information of adult trees (not deviated from a random pattern) may represent conditions of higher gene flow that were present before or very close to the implementation of the first cutting cycle in the stand (ca. 16 years ago). Consequently, the positive spatial autocorrelation observed in saplings is interpreted as evidence of disruption in the local pattern of gene flow probably produced by selective logging.

Even under random mating, in conditions of limited seed dispersal it can be expected an increase in relatedness at decreasing spatial scales (Vekemans and Hardy, 2004). Seeds of Swietenia macrophylla remain viable for only few months, so seedlings present in the area have resulted unequivocally from seeds recently produced. Therefore, progeny could reflect the occurrence of current ecological conditions that affect gene admixture in sites subjected to selecting logging. For example, it has been documented that small-remnant trees of S. macrophylla in the Mayan zone seems to show a limited seed dispersal (Cámara-Cabrales and Kelty, 2009). So the higher genetic relatedness in the group of saplings should be linked to the limited seed dispersal caused by selective logging. This is because the progeny has been produced mainly by small and nearby remnant trees, as the largest individuals have been almost entirely removed (Santos-Jiménez et al., 2005).

In addition, a restricted gene movement could also be explained by a limited pollen movement, as anthropogenic activities have the potential to disrupt mutualistic interactions. First, changes in behaviour of pollinators affecting reproductive success in tropical trees have been detected in disturbed forests (Ghazoul et al., 1998; Ghazoul and McLeish, 2001). Second, outcrossing rates may be also diminished by a reduction in the proportion of flowering trees in logged forests (Murawski and Hamrick, 1991; Murawski et al., 1994; Obayashi et al., 2002). Third, the average effective number of pollen donors and the number of sires per mother were lower in isolated patches than in continuous forests (Rosas et al., 2011). These three effects suggest that in our study, saplings could have been derived from a subset of adult trees, whereas a higher number of reproductive individuals were involved in the production of current adult trees. Therefore it seems that both, the alteration of the interaction with pollinators and the limited seed dispersal produced by selective logging could be involved in the higher genetic structure observed in the group of saplings (Lourmas et al., 2007).

The results derived from the autocorrelation analyses were supported by the results obtained from the factorial correspondence analyses that indicated a higher genetic structure within the saplings groups. Although the factorial correspondence analysis is not an explicit spatial approach to test for genetic structure, it showed that the multi-locus genotypic variation of adult trees was twice as much as the observed in the group of saplings. This result agreed with the observed for other tropical tree species. For example, a reduction in the number of genotypes has been documented as a result of selective logging (Degen et al., 2006), whereas the number of mutilocus genotypes registered in seedlings was a half compared with those present in adult trees of Swietenia macrophylla located in a forest fragment of Brazil subjected to selective logging (André et al., 2008).

Conservation considerations. The magnitude of the Moran's Index of about 0.05 obtained in the autocorrelation analysis has been observed commonly among tropical tree species. However, the positive autocorrelation found in the group of saplings at distances of up to $1,000 \mathrm{~m}$ has not been frequently reported in literature. The widespread signal for the spatial genetic structure in saplings and the high coefficient of fixation of about 0.4 , indicate mating among relatives probably produced by limits to gene flow via seed dispersal and pollen movement. These high values for the coefficient of fixation are important for the future conservation of populations, as the occurrence of inbreeding in naturally outcrossed species could conduce to the loss of fitness (Frankham et al., 2010). Therefore, studies addressing the fitness performance of progeny are a priority for the conservation of this species at the Mayan zone. However, it would be necessary for future studies to evaluate the genetic structure and genetic diversity considering more sites, as for example, the volume of wood removed and the areas set aside for logging greatly vary among different ejidos within the Mayan zone (Santos-Jiménez et al., 2005). To evaluate if adults of Swietenia macrophylla can be utilized as a control group (i.e., indicating conditions before the implementation of selective logging), the experimental design should include comparisons between adults and saplings in zones with and without selective logging.

The integration of ecological data available in literature with the genetic information about Swietenia macrophylla in the Mayan zone provided by this study, indicates that the current management program performed under the current conditions (i.e. 25-y cycles, minimum cutting diameter $\geq$ $55 \mathrm{~cm}$ ), should be reviewed in order to assure not only natural regeneration, but the maintenance of genetic diversity. It is important to note that the genetic differences (loss of alleles, higher genetic structure) observed between adults and saplings in this study, are related to the implementation of the first cutting cycle, some $16 \mathrm{y}$ ago. Therefore, future cutting cycles of adult reproductive trees could reduce the effective population size, which in consequence could produce higher negative impact on allelic richness and heterozygosity. The protection of several large individuals as pollen donors and seed sources should occur to increase gene flow and the effective population size. Large individuals are crucial to maintain the genetic diversity of the northernmost big-leaf mahogany populations, and the Mayan zone inhabitants' income as well. 


\section{Acknowledgements}

Authors are grateful to the Organización de Ejidos Productores Forestales de la Zona Maya, S. C., in particular to Ing. V. J. Santos Jiménez for the access to the site. Field assistance was provided by H. Salazar, L. Y. Bustos and M. Chan. We also acknowledge the comments and suggestions provided by two anonymous reviewers that greatly improved the quality of this manuscript. This study was funded by the Comisión Nacional para el estudio de la Biodiversidad (CONABIO).

\section{Literature cited}

Alcalá R.E., Salazar H., Gutiérrez-Granados G. and Snook L.K. 2014. Genetic structure and genetic diversity of Swietenia macrophylla (Meliaceae): implications for sustainable forest management in Mexico. Journal of Tropical Forest Science 26:142152.

André T., Lemes M.R., Grogran J. and Gribel R. 2008. Post-logging loss of genetic diversity in a mahogany (Swietenia macrophylla King, Meliaceae) population in Brazilian Amazonia. Forest Ecology and Management 255:340-345.

Asner G.P., Knapp D.E., Broadbent E.N., Oliviera P.J.C., Keller M. and Silva J.N. 2005. Selective logging in the Brazilian Amazon. Science 310:480-482.

Belkhir K., Borsa P., Chikhi L., Raufaste N. and Bonhomme F. 1996-2004. GENETIX 4.05, logiciel sous Windows TM pour la génétique des populations. Laboratoire Génome, Populations, Interactions, Université de Montpellier II, Montpellier, France.

Biscaia-de Lacerda A.E, Kanashiro M. and Sebbenn A.M. 2008. Effects of reduced impact logging on genetic diversity and spatial genetic structure of a Hymenaea courbaril population in the Brazilian Amazon Forest. Forest Ecology and Management 255:1034-1043.

Bray D.B., Merino-Pérez L., Negreros-Castillo P., Segura-Warnholtz G., Torres-Rojo J.M. and Vester H.F.M. 2003. Mexico's community-managed forests as a global model for sustainable landscapes. Conservation Biology 17:672-677.

Cámara-Cabrales L. and Kelty M.J. 2009. Seed dispersal of bigleaf mahogany (Swietenia macrophylla) and its role in natural forest management in the Yucatan Peninsula, Mexico. Journal of Tropical Forest Sciences 21:235-245.

Céspedes M., Gutierrez M.V., Holbrook N.M. and Rocha O.J. 2003. Restoration of genetic diversity in the dry forest tree Swietenia macrophylla (Meliaceae) after pasture abandonment in Costa Rica. Molecular Ecology 12:3201-3212.

Cloutier D., Kanashiro M., Ciampi A.Y. and Schoen D.J. 2007. Impact of selective logging on inbreeding and gene dispersal in an Amazonian tree population of Carapa guianensis Aubl. Molecular Ecology 16:797-809.

Collevatti R.S., Grattapaglia D. and Hay J.D. 2001. Population genetic structure of the endangered tropical tree species Caryocar brasiliense, based of variability at microsatellite loci. Molecular Ecology 10:349-356.

Cunningham S.A. 2000. Depressed pollination in habitat fragments causes low fruit set. Proceedings of the Royal Society of London B 267:1149-1152.
Cushman S.A. 2006. Effects of habitat loss and fragmentation on amphibians: a review and prospectus. Biological Conservation 128:231-240.

Degen B. 2000. SGS: Spatial Genetic Software. Computer program and user's manual. Disponible en: <http://kourou.cirad. fr/genetique/software.html>

Degen B., Petit R. and Kremer A. 2001. SGS-Spatial Genetic Software: A computer program for analysis of spatial genetic and phenotypic structures of individuals and populations. Journal of Heredity 92:447-448.

Degen B., Blanc L., Caron H., Maggia L., Kremer A. and GourletFleury S. 2006. Impact of selective logging on genetic composition and demographic structure of four tropical tree species. Biological Conservation 131:386-401.

Dick C.W., Hardy O.J., Jones F.A. and Petit R.J. 2008. Spatial scales of pollen and seed-mediated gene flow in tropical rain forest trees. Tropical Plant Biology 1:20-33.

Doyle J.J. and Doyle J.L. 1987. A rapid DNA isolation procedure for small quantities of fresh leaf tissue. Phytochemical Bulletin 19:11-15.

Excoffier L., Laval G. and Schneider S. 2005. Arlequin (version 3.0): An integrated software package for population genetics data analysis. Evolutionary Bioinformatics 1:47-50.

Frankham R., Ballou J. and Briscoe D.A. 2010. Introduction to Conservation Genetics. Cambridge University Press, New York.

Franklin I.R. 1980. Evolutionary change in small populations. In: Soule M.E. and Wilcox B.A. Eds. Conservation Biology: An Evolutionary-Ecological Perspective, pp. 135-149, Sinauer Associates, Sunderland.

Ghazoul J. and McLeish M. 2001. Reproductive ecology of tropical forest trees in logged and fragmented habitats in Thailand and Costa Rica. Plant Ecology 153:335-345.

Ghazoul J., Liston K.A. and Boyle T.J.B. 1998. Disturbance-induced density-dependent seed set in Shorea siamensis (Dipterocarpaceae), a tropical forest tree. Journal of Ecology 86:462473.

Gillies A.C.M., Navarro C., Lowe A.J., Newton A.C., Hernández M., Wilson J. and Cornelius J.P. 1999. Genetic diversity in Mesoamerican populations of mahogany (Swietenia macrophylla), assessed using RAPDs. Heredity 83:722-732.

Gutiérrez-Granados G. 2010. Efectos directos e indirectos de la extracción forestal sobre la diversidad vegetal y la interacción mamífero-planta en la selva Maya de Quintana Roo. Tesis Doctoral, Instituto de Ecología, Universidad Nacional Autónoma de México, México D.F. 200 pp.

Gutiérrez-Granados G. y Dirzo R. 2009. Remoción de semillas, herbivoría y reclutamiento de plántulas de Brosimum alicastrum (Moraceae) en sitios con manejo forestal contrastante de la selva Maya, Quintana Roo, México. Boletín de la Sociedad Botánica de México 85:51-58.

Gutiérrez-Granados G., Juárez V. and Alcalá R.E. 2011. Natural and human disturbances affect natural regeneration of Swietenia macrophylla: Implications for rainforest management. Forest Ecology and Management 262:161-169.

Hardesty B.D, Dick C.W., Kremer A., Hubell S. and Bermingham E. 2005. Spatial genetic structure of Simarouba amara Aubl. (Simaroubaceae), a dioecius, animal-dispersed Neotropical tree, on Barro Colorado Island, Panama. Heredity 95:290-297. 
Hedrick P.W. 2000. Genetics of Populations. 2nd ed. Jones and Bartlett Publishers, Sudbury.

Holdridge L.R. 1967. Life zone ecology.Tropical Science Center, San José.

Jennings S.B., Brown N.D., Boshier D.H., Whitmore T.C. and Lopes J. do C.A. 2001. Ecology provides a pragmatic solution to the maintenance of genetic diversity in sustainable managed tropical rain forests. Forest Ecology and Management 154:1-10.

Latouche-Hallé C., Ramboer A., Bandou E., Caron H. and Kremer A. 2004. Long-distance pollen flow and tolerance to selfing in a neotropical tree species. Molecular Ecology 13:1055-1064.

Lee S.L. 2000. Mating system parameters of Dryobalanops aromatica Gaertn. f. (Dipterocarpaceae) in three different forest types and a seed orchard. Heredity 85:338-345.

Lemes M.R., Brondani R.P.V. and Grattapaglia D. 2002. Multiplexed systems of microsatellite markers for genetic analysis in mahogany Swietenia macrophylla King (Meliaceae), a threatened Netropical timber species. Journal of Heredity 93:287290.

Lemes M.R., Gribel R., Proctor J. and Grattapaglia D. 2003. Population genetic structure of mahogany (Swietenia macrophylla King, Meliaceae) across the Brazilian Amazon, based on variation at microsatellite loci: implications for conservation. Molecular Ecology 12:2875-2883.

Lourmas M., Kjellberg F., Dessard H., Joly H.I. and Chevallier M.H. 2007. Reduced density due to logging and its consequences on mating system and pollen flow in the African mahogany Entandrophragma cylindricum. Heredity 99:151-160.

Lowe A.J., Boshier D., Ward M., Bacles C.F.E. and Navarro C. 2005. Genetics resource impacts of habitat loss and degradation; reconciling empirical evidence and predicted theory for neotropical trees. Heredity 95:255-273.

Lowe A.J., Jourde B., Breyne P., Colpaert N., Navarro C., Wilson J. and Cavers S. 2003. Fine-scale structure and gene flow within Costa Rican populations of mahogany (Swietenia macrophylla). Heredity 90:268-275.

Murawski D.A. and Hamrick J.L. 1991. The effect of the density of flowering individuals on the mating systems of nine tropical tree species. Heredity 67:167-174.

Murawski D.A., Gunatilleke I.A.U.N. and Bawa K.S. 1994. The effects of selective logging on inbreeding in Shorea megistophylla (Dipterocarpaceae) from Sri Lanka. Conservation Biology 8:997-1002.

Navarro C., Boshier D., Cavers S. and Lowe A. 2010. Genetic resources and conservation of Mahogany in Mesoamerica. In: Mery G., Katila P., Galloway G., Alfaro R., Kanninen M., Lobovikov M. and Varjo J. Eds. Forests and Society - Responding to Global Drivers of Change. pp. 369-383. International Union of Forest Research Organizations (World Series Vol. 25), Vienna. Disponible en <http://www.iufro.org/science/special/wfse/forests-society-global-drivers/>

Novick R.R., Dick C.W., Lemes M.R., Navarro C., Caccone A. and Bermingham E. 2003. Genetic structure of Mesoamerican populations of big-leaf mahogany (Swietenia macrophylla) inferred from microsatellite analysis. Molecular Ecology 12:2885-2893.

Obayashi K., Tsumura Y., Ihara-Ujino T., Niiyama K., Tanouchi H., Suyama Y., Washitani I., Lee C-T., Lee S.L. and Muham$\operatorname{mad}$ N. 2002. Genetic diversity and outcrossing rate between undisturbed and selectively logged forests of Shorea curtisii (Dipterocarpaceae) using microsatellite DNA analysis. International Journal of Plant Sciences 163:151-158.

Rajora O.P., Rahman M.H., Buchert G.P. and Dancik B.P. 2000. Microsatellite DNA analysis of genetic efforts of harvesting in old-growth eastern white pine (Pinus strobus) in Ontario, Canada. Molecular Ecology 9:339-348.

Rebollar-Domínguez S., Santos-Jiménez V. and Sánchez-Aguilar R.L. 2002. Estrategias de recuperación de selvas en dos ejidos de Quintana Roo, México. Madera y Bosques 8:19-38.

Rosas F., Quesada M., Lobo J.A. and Sork V.L. 2011. Effects of habitat fragmentation on pollen flow and genetic diversity of the endangered tropical tree Swietenia humilis (Meliaceae). Biological Conservation 144:3082-3088.

Santos-Jiménez V., Mas-Kantún P., López C., and Snook L.K. 2005. El manejo forestal y la caoba en los ejidos de la zona maya, México. Desarrollo histórico, condiciones actuales y perspectivas. Recursos Naturales y Ambiente 44:27-36.

Sebbenn A.M., Degen B., Azevedo V.C.R., Silva M.B., Lacerda A.B. de, Ciampi A.Y., Kanashiro M., Carneiro F. da S., Thompson I. and Loveless M.D. 2008. Modelling the long-term impact of selective logging on genetic diversity and demographic structure of four tropical tree species in the Amazon forest. Forest Ecology and Management 254:335-349.

Shono K. and Snook L.K. 2006. Growth of big-leaf mahogany (Swietenia macrophylla) in natural forests in Belize. Journal of Tropical Forest Science 18:66-73.

Sih A., Jonsson B.G. and Luikart G. 2000. Habitat loss: ecological, evolutionary and genetic consequences. Trends in Ecology and Evolution 15:132-134.

Silva M.B., Kanashiro M., Ciampi A.Y., Thompson I. and Sebbenn A.M. 2008. Genetic effects of selective logging and pollen gene flow in a low-density population of the dioecious tropical tree Bagassa guianensis in the Brazilian Amazon. Forest Ecology and Management 255:1548-1558.

Sist P., Sheil D., Kartawinata K. and Priyadi H. 2003. Reducedimpact logging in Indonesian Borneo: some results confirming the need for new silvicultural prescriptions. Forest Ecology and Management 179:415-427.

Smouse P.E. and Peakall R. 1999. Spatial autocorrelation analysis of individual multiallele and multilocus genetic structure. $\mathrm{He}$ redity $82: 561-573$.

Snook L.K. 1998. Sustaining harvest of mahogany (Swietenia macrophylla King) from Mexico's Yucatán forests: past, present and future. In: Primack R. B., Bray D., Galleti H.A. and Ponciano I. Eds. Timber, Tourists and Temples: Conservation and Development of Maya Forests of Belize, Guatemala and Mexico. pp. 61-80, Island Press, Washington D.C.

Snook L.K. 2003. Regeneration, growth and sustainability of mahogany in Mexico's Yucatan forests. In: Lugo A.E., Figueroa Colón J.C. and Alayón M. Eds. Big-leaf Mahogany: Genetics, Ecology, and Management, pp. 169-192. Ecological Studies 159, Springer-Verlag, New York

Snook L.K., Cámara-Cabrales L. and Kelty M.J. 2005. Six years of seed production by mahogany trees (Swietenia macrophylla King): patterns of variation and implications for sustainability. Forest Ecology and Management 206:221-235.

Sokal R.R. and Rohlf F.J. 1995. Biometry: the Principles and Practice of Statistics in Biological Research. W.H. Freeman and Company, New York. 
Trujillo-Sierra J.E., Delgado-Valerio P., Ramírez-Morillo I., Rebolledo-Camacho V. and Pérez-Nasser N. 2013. Variación genética en poblaciones mexicanas de Swietenia macrophylla King, una especie tropical en expansión geográfica reciente. Botanical Sciences 91:307-317.

Vester H.F.M. and Navarro-Martínez M.A. 2005. Ecological issues in community tropical forest management in Quintana Roo, Mexico. In: Bray D.B., Merino Pérez L. and Barry D. Eds. The Community Forests of Mexico: Managing for Sustainable Landscapes, pp. 183-214. University of Texas Press, Austin.

Vekemans X. and Hardy O.J. 2004. New insights from fine-scale spatial genetic structure analyses in plant populations. Molecular Ecology 13:921-935.

Received: September 18th, 2014

Accepted: December 17th, 2014
White G.M., Boshier D.H. and Powell W. 1999. Genetic variation within a fragmented population of Swietenia humilis Zucc. Molecular Ecology 8:1899-1909.

White G.M., Boshier D.H. and Powell W. 2002. Increased pollen flow counteracts fragmentation in a tropical dry forest: An example from Swietenia humilis Zuccarini. Proceedings of the National Academy of Sciences of the United States of America 99:2038-2042.

Wright S.J. and Muller-Landau H.C. 2006. The future of tropical forest species. Biotropica 38:287-301.

Young A., Boyle T. and Brown T. 1996. The population genetic consequences of habitat fragmentation for plants. Trends in Ecology and Evolution 11:413-418. 